\title{
A question of sovereignty?
}

\section{The EU's policy on Taiwan's participation in international organisations}

\author{
Sigrid Winkler
}

Received: 21 May 2012 /Revised: 12 October 2012 / Accepted: 16 November 2012 /

Published online: 11 December 2012

(C) Springer-Verlag Berlin Heidelberg 2012

\begin{abstract}
Taiwan's efforts to take part in international organisations (IOs) have received little backing from the international community owing to Taiwan's contested sovereignty. This article investigates under what circumstances and how the European Union (EU) supported Taiwan's participation in IOs and agreements by examining the role of the EU in three success stories: the World Trade Organization (WTO), the Government Procurement Agreement (GPA) and the World Health Organization (WHO). The analysis of six factors that shaped the EU's approach shows that a strong EU interest in Taiwan's IO participation was a precondition for its support and that once this precondition was met, applicable membership/participation criteria and opportunities for circumventing or neutralising China's opposition then gained in importance. A supportive United States (US) stance could function as a trigger for EU support. Two counterintuitive findings are that the radicalisation of Taiwan's own strategy fostered increased EU activity in brokering compromises between Taiwan and China and that the EU's decision-making mechanisms did not play a decisive role in the formulation of its support policies.
\end{abstract}

\section{Introduction}

Taiwan's path into international organisations (IOs) has been a stony one. Only some of the states that have diplomatic relations with Taipei have given their full support to

This article is based on the author's Ph.D. thesis, defended at the Vrije Universiteit Brussel in Brussels, Belgium. It was first presented at the Annual European Association for Taiwan Studies (EATS) 2011 Conference in Ljubljana, Slovenia. The text was further developed during the author's stay at the Center for Chinese Studies at the National Central Library in Taipei with the Taiwan Fellowship programme of the $\underline{\text { ROC Ministry of Foreign Affairs. }}$

S. Winkler $(\bowtie)$

Institute for European Studies, Vrije Universiteit Brussel, Pleinlaan 5, 1050 Brussels, Belgium

e-mail: sigrid.winkler@vub.ac.be 
its membership: other countries, whilst they may have an interest in seeing Taiwan integrated in some ways into particular IOs, have had to balance this stance with their "one China" policy. This has been the case, for example, with the European Union $(\mathrm{EU})^{1}$ : from its perspective, Taiwan's problematic sovereignty is the overarching problem when trying to formulate policies to support Taipei's participation in IOs.

Against this background, the article will investigate under what circumstances and how the EU has supported Taiwan's participation in IOs. The three case studies under consideration involve the World Trade Organization (WTO), the WTO's Government Procurement Agreement (GPA), an agreement within the WTO, and the World Health Organization (WHO). The aim is to analyse the underlying dynamics that shaped the EU's policy in these cases in order to understand this aspect of EU-Taiwan relations better. It is not the purpose of this article to claim that the EU was the most relevant power in gaining entry into those organisations for Taiwan.

In order to answer its research question, the article will first present some ideas on how to define sovereignty in a case like Taiwan's before going on to outline methodological considerations affecting the comparative case study design and then introducing six factors which, in the empirical analysis, will be tested for their influence on EU policy.

In the following, short overviews will be given of the three case studies, contextualising the six factors used in the analysis. In the next step, these factors will then be dealt with one by one in a cross-case comparison. Finally, some conclusions will be drawn on the circumstances necessary for the EU to support Taiwan's participation in IOs and on the nature of this support.

\section{Considerations regarding Taiwan's sovereignty}

This research applies an innovative tripartite conceptualisation of sovereignty ${ }^{2}$ within which to frame the problem: international legal sovereignty based on the recognition of statehood; domestic sovereignty, understood as a domestic government's authority and control over its own territory and population ${ }^{3}$; and functional sovereignty, meaning the ability of a non-recognised state to conduct international relations but usually only on specific issues. ${ }^{4}$

\footnotetext{
${ }^{1}$ European integration has been a longstanding project, with the EU, created in 1993 with the Maastricht Treaty, being only the latest result. It would, therefore, be more correct to refer in some parts of this study to the European Community (EC) or the European Economic Community (EEC), but for simplicity, we use "EU" to refer to all of these incarnations.

${ }^{2}$ The author initially developed this conceptualisation in a journal article on EU-Taiwan relations in the WTO and subsequently, also used it in two book chapters: first, on the EU's policy on Taiwan's participation in the WTO, the WHO and the United Nations and second, on EU-Taiwan relations in general. For a more detailed elaboration of these concepts, please refer to these earlier publications (Winkler 2008; Winkler 2009; Lim and Winkler 2012).

${ }^{3}$ The concepts of domestic sovereignty and international legal sovereignty are inspired by Stephen Krasner's (1999) typology.

${ }^{4}$ The term "functional sovereignty" has already been used with many different connotations (for instance: Kollek 1988; Nachmias 1999). A Google.com search produces over 4 million entries. This study, however, adopts a new approach in characterising the ability of an entity with insufficient recognition to engage in international organisations.
} 
The concepts of domestic sovereignty and international legal sovereignty are sufficient to characterise most states in the international community. Taiwan, however, possesses only the internal face of sovereignty: domestic sovereignty. The external face of sovereignty, international legal sovereignty, enables states to maintain official relations with other states and to take part in all areas of international relations. In order to be the equal of other states in the international community, recognition by a large number of other states is necessary. Being recognised by only 23 states, and none of the big global powers, Taiwan does not possess a sufficient level of international legal sovereignty and is excluded from many aspects of international relations.

Taiwan did, however, manage to develop an international presence: through informal but substantive relations with states that do not entertain diplomatic relations with it and through participation in a small but growing number of IOs. The concept of international legal sovereignty, therefore, does not characterise Taiwan's actorness in international relations.

Because of its domestic sovereignty, Taiwan's government is the final authority on all matters relating to Taiwan's territory and population. Although it is China that claims international legal sovereignty over Taiwan, any third state wanting to interact with the latter needs to enter into contact with the Taiwanese government. This phenomenon, whereby third states engage in relations with Taiwan that are limited to specific issue-areas of interest to these states, will here be called functional sovereignty. It enables Taiwan to be active in some areas of international relations.

Viewing sovereignty from this angle not only helps to explain Taiwan's involvement in international relations - this perspective can also be used to characterise the motives behind the policies and interactions discussed in this study. For instance, as none of the EU member states recognises Taiwan, it can be assumed that the EU will only support Taiwan's participation in IOs where it can be defended on the basis of functional sovereignty. This would exclude full membership of state-based organisations, for which international legal sovereignty is necessary. On the other hand, Taiwan is liable to use participation in IOs to portray itself as a fully fledged state with international legal sovereignty, despite not having a sufficient level of diplomatic recognition. China may fear exactly this situation - that other states would indeed accept Taiwan as a fully fledged sovereign state once they are accustomed to having contact with Taiwan in IOs. It has to be underlined, however, that these concepts have a purely analytical value for categorising the policies and positions of actors involved; the actors themselves do not refer to this tripartite conceptualisation.

\section{Methodology and hypotheses}

In a comparative study of three cases, WTO, GPA and WHO, this article studies six factors that shape European policy on Taiwan's participation in IOs. Two of these factors are internal to the EU: its own decision-making processes and its interest in Taiwan's participation in particular IOs. Four external factors also influence EU policy: the membership criteria of the IOs in question, changes in the Taiwanese campaign vis-àvis these organisations, the Chinese position; and the role of the United States (US).

The three case studies have been chosen on the basis of a most similar case study design, as in all three cases, the EU eventually supported Taiwan's entry into the 
Table 1 Hypotheses about six factors

$\begin{array}{ll}\text { EU interest } & \text { The EU will support Taiwan's entry into a particular IO only if it estimates } \\ \text { that one of its own major interests will be advanced thereby } & \text { The EU uses different decision-making procedures for different issues. } \\ \text { EU decision-making } & \begin{array}{l}\text { Decision-making based on qualified majority voting (QMV) in the Council } \\ \text { of Ministers will improve the chances of EU support, whilst decision-making } \\ \text { based on consensus or unanimity in the intergovernmental method will } \\ \text { decrease the chances of EU support }\end{array} \\ & \text { The EU will only extend support if membership or other forms of } \\ \text { participation can be justified on the basis Taiwan's functional sovereignty } \\ \text { Membership criteria } \\ \text { The EU will only support Taiwan's participation in IOs provided Taiwan } \\ \text { bases its own campaign on functional sovereignty and not on the goal } \\ \text { of attaining international legal sovereignty } \\ \text { The EU will only support Taiwan's participation in international organisations } \\ \text { when China's opposition is weak, or can be circumvented/neutralised } \\ \text { Thina } \\ \text { The EU will be more strongly motivated to support Taiwan's participation } \\ \text { in international organisations if the US supports the same goal, as their } \\ \text { coordinated efforts increase the likelihood of success }\end{array}$

relevant IO. ${ }^{5}$ The six factors used to explain EU policy have different values in the case studies, making it possible to see which are more and which less influential in shaping EU policy, as variation can be observed in a cross-case comparison. Furthermore, another criterion for the case selection was the availability of data, as in other potential case studies, not enough data was available on the EU's role in supporting Taiwan's participation in the organisation. ${ }^{6}$

The case studies cover a time span from 1990 to 2012, from the first Taiwanese attempt to become a contracting party to the General Agreement on Tariffs and Trade (GATT) to Taiwan's fourth year as observer in the WHO World Health Assembly (WHA).

This work is based on an inductive approach. The six factors were chosen after some exploratory research on the issue, where they were distilled as the factors most likely to shape EU policy on Taiwan's participation in IOs. Connected with each of the factors is a hypothesis (see Table 1), which will be tested during the in-depth analysis of the three case studies.

\section{Overview of case studies}

\section{The World Trade Organization}

The WTO is a multilateral body which aim is to liberalise world trade by abolishing trade barriers. The WTO was not established until 1995. The members of the WTO

\footnotetext{
${ }_{5}^{5}$ Although it might also have been interesting to include cases in which the EU did not support Taiwan's participation, to see what its motives were, this has proven to be impossible: in these cases, there is simply not enough material available to investigate what shaped its position, as the EU then remained silent on the issue (at least in public).

${ }^{6}$ For some general reading on the comparative methods and case selection that influenced this study, see, for instance, George and Benett (2004), King et al. (1994) and Pierce (2008).
} 
(like those of its predecessor, the GATT) decided that, in order to liberalise all world trade without being hindered by national borders, in addition to states, it would be open to separate customs territories, which do not possess international legal sovereignty but do have functional sovereignty in trade matters (GATT 1947, Art. XXXIII; WTO 1995, Art. XII para. 1).

Taiwan filed its application to become a GATT contracting party under the name "Separate Customs Territory of Taiwan, Penghu, Kinmen and Matsu" on 1 January 1990. With this application, Taiwan justified its approach exclusively on the basis of its functional sovereignty. At this point, it was amongst the world's 15 largest trading powers. ${ }^{7}$ China (GATT 1990) immediately replied to Taiwan's application with the following statement:

"Now the Taiwan authorities, posing as the government of a sovereign state, have gone so far as to apply, on behalf of the so-called 'separate customs territory of Taiwan, Penghu, Kinmen and Mazu', for accession to the GATT. This is utterly illegal."

China was most worried that if Taiwan acceded to the GATT, even as a separate customs territory, this would confirm that it was a state with international legal sovereignty. However, as China was itself still negotiating its GATT/WTO entry, and at the start of the 1990s, its economic power was still comparatively weak, its request that the GATT should immediately reject the Taiwanese application was not complied with.

The EU was initially divided as to whether or not Taiwan could qualify as a GATT contracting party. Whilst the European Commission was favourable (Interview 1 2007; Interview 2 2007), the then so-called 113 Committee (Communautés européennes, Le Conseil 1990, 6), however, in which EU member state representatives prepared decisions of the Council of the European Union, underlined that support for Taiwan's GATT application would lead to "a political problem concerning Mainland China". Although Taiwan's GATT application was based on a functional approach, the Council still considered matters of international legal sovereignty. In the end, however, economic considerations, especially a trade disadvantage in relation to the US, which trade with Taiwan was stronger than the EU's (Interview 3 2008), induced the Council to acquiesce.

In 1992, the GATT Council decided to set up a working party for the entry of "Chinese Taipei", as Taiwan's lengthy name was abbreviated in the organisation. Whilst this decision paved the way for Taiwan's eventual WTO entry, it also, finally, responded to some of China's concerns. It was decided that Taiwan should not enter the organisation before China, although the working parties of China and Taiwan would proceed independently of each other (GATT Council 1992, 3-4).

Taiwan's accession negotiations moved forward without major problems. With the establishment of the WTO, Taiwan's GATT working party became a WTO working

\footnotetext{
7 These figures oscillate in scholarly literature between describing Taiwan as the 13th and the 15th biggest trading power at the beginning of the 1990s (Cho 2001, 85; Yeh 1990, 79; Feinermann 1992, 40; Chang 1994, 216). The European Parliament $(1993,7)$ described Taiwan in 1993 as the world's 12th largest exporter.
} 
party. By 1998, the EU had concluded its bilateral negotiations with Chinese Taipei (European Union 1998), but as Taiwan's entry was coupled with China's, a few more years had to go by before Chinese Taipei could join the organisation.

During the last years of the negotiations, in 1999 and 2000, China again tried to interfere in Taiwan's accession, first, by attempting to alter Taiwan's name in the organisation to "China's Separate Customs Territory of Taiwan, Penghu, Kinmen and Matsu" (Cho 2003, 8; Hsieh 2005, 1204) and then by proposing, to its own working party, language specifying that Taiwan was a separate customs territory of China. These attempts provoked strong reactions in the US Congress, which also pressured the US president not to accept them (United States of America 2000, 17912).

At the Doha Ministerial Conference, China's WTO accession was eventually approved on 10 November 2001, and Taiwan's on 11 November (WTO 2001a; WTO 2001b). After domestic ratification, the Separate Customs Territory of Taiwan, Penghu, Kinmen and Matsu became a WTO member on 1 January 2002 (WTO 2008).

Throughout the process, the EU had supported Chinese Taipei's membership of the WTO. The EU had a strong economic interest in Taiwan's WTO accession. Although WTO negotiations fall within the Common Commercial Policy of the EU, with a strong role in the negotiations for the European Commission, and only a requirement for a qualified majority in the EU Council to conclude them, in this case, the Council decided to act by unanimity (European Union 2001). Even the stricter decisionmaking procedure, however, did not change the outcome of the vote, as the decision had been in the making for several years.

The WTO's membership criteria were suitable for accommodating an entity like Taiwan on the basis of functional sovereignty, and Taiwan had consistently adopted this approach throughout its accession process. China showed strong opposition and tried to dictate the terms of Taiwan's entry, at least, but its concerns did not succeed in deterring the EU from its supportive stance. The EU was less outspoken than the US but both had a similar interest in Taiwan's WTO membership and their combined power was a major factor in making Taiwan's WTO accession possible.

With Taiwan's accession, however, the sovereignty problem was not yet overcome in the WTO. It quickly resurfaced, notably during Taiwan's accession to the GPA.

\section{The Government Procurement Agreement}

The GPA is an agreement within the WTO that only a limited number of WTO members have joined. Its goal is to abolish discrimination against products and suppliers from other GPA parties in government procurement procedures (WTO 1996, preamble). For this reason, every acceding member needs to negotiate, with the existing contracting parties, a list of government procurement entities to which the GPA is applicable. This list is then presented as Appendix I to the agreement. Appendix I consists of five annexes, of which Annex 1 lists the central government procurement entities covered by the agreement (WTO n.d.). It was this Annex 1 that, in Taiwan's case, raised problems of sovereignty during Taiwan's GPA accession process. However, as the GPA is open to all WTO members, it also provides for separate customs territories to join (WTO 1996, Art. XXIV para. 2). 
In 1994, Taiwan formally applied to join the GPA (Interim Committee on Government Procurement 1994a) and was granted observer status whilst negotiating its entry (Interim Committee on Government Procurement 1994b, Art. B). In 1994, its representatives were still expressing their hope that Taiwan would join by the end of that year (Interim Committee on Government Procurement 1994b, Art. B). However, this deadline was postponed again and again for years: first, because Taiwan's WTO membership was a precondition for acceding to the GPA, and second, because the negotiations on technical issues relating to Taiwan's government procurement offer took longer than initially expected. Thus, Taiwan's GPA negotiations were still going on after it had become a WTO member (Committee on Government Procurement 2002, Art. D (i)), at which point, it was negotiating on the basis of its third revised offer, which it had tabled in January 2002, shortly before the meeting.

After its own WTO entry, China was granted observer status in the first subsequent meeting of the Government Procurement Committee, thereby gaining the right to speak at the meetings. China immediately used this opportunity to voice its concern about language used in Annex 1 of Taiwan's revised offer (Committee on Government Procurement 2002, Art. D (i) para. 26):

"The representative of China [underlined in original, SW] said that China was neither opposed to the accession of Chinese Taipei to the Agreement nor intent on delaying the process of accession. However, document GPA/SPEC/1/ Rev. 2 contained some nomenclatures which were not consistent with both the Report of the Working Party on the Accession of Chinese Taipei to the WTO and the Protocol of Accession which were the basic legal documents for the accession of Chinese Taipei as a separate customs territory. China requested that this problem be resolved before a decision were taken by the Committee on Chinese Taipei's accession to the Agreement."

China's problem was that the text contained the names of Taiwan's central government entities, such as "Office of the President", "Ministry of Foreign Affairs" and "Department of Defence" (Interview 4 2010; Interview 5 2010; Interview 6 2010). According to China's interpretation, as Taiwan was not to enter the agreement as a sovereign state but as a separate customs territory, such wording would wrongly indicate international legal sovereignty for Taiwan. Taiwan had used the same formulations in its earlier offers, ${ }^{8}$ and none of the other GPA members had ever found them a reason to raise questions about Taiwan's sovereignty. It was interesting, therefore, to see how much weight was given to China's concern, even though it was only an observer and not entitled to vote on Chinese Taipei's entry into the agreement.

The issue of sovereignty implications in Taiwan's Annex 1 was not easily resolved. For reasons of legal clarity, it was necessary to use the same names as were used in the Taiwanese domestic context. Discussions, therefore, started about including a footnote in Taiwan's accession documents denying any implication of sovereignty. However, Taiwan, ruled at this point by the pro-independence oriented Democratic Progressive Party (DPP), began to change the course of its campaign for participation in IOs. Mere participation was no longer important: the strategy now was to portray Taiwan as a sovereign country. The focus changed from functional sovereignty to

\footnotetext{
$\overline{8}$ Taiwan had tabled the initial draft offer in 1995 and submitted revised offers in 1996, 1997 and 2002.
} 
international legal sovereignty. ${ }^{9}$ Hence, this government was not ready to accept solutions that were perceived as undermining Taiwan's sovereignty.

In 2006, without explicitly mentioning Taiwan, the EU and the US tabled a proposal for a general decision rejecting the idea that the use of terminology in GPA accession decisions regarding any separate customs territory should carry an implication of sovereignty. ${ }^{10}$ The following text was subsequently adopted as Decision GPA/87 (Committee on Government Procurement 2006):

"With respect to the nomenclature and other terminology used in a decision of accession to the Agreement, including in appendices and annexes, that have been provided by any delegation representing a separate customs territory, the Parties note that the nomenclature and other terminology used have been provided only for the purpose of providing clarity in defining commitments in the framework of the accession to the Agreement. The Parties also note that none of the nomenclature and other terminology used have implications for sovereignty."

The problem of how this decision should be implemented in Taiwan's case persisted, however: was a footnote or a reference to Decision GPA/87 still necessary in Taiwan's GPA accession text? It appears that this was China's minimum demand. Taiwan's government, however, was strictly opposed to this option, as it rejected the idea that the WTO should be allowed to pass judgment on whether Taiwan was a sovereign state or not (Interview 7 2007; Interview 8 2008; Interview 9 2007).

Taiwan's GPA accession was discussed less and less often in the official meetings of the GPA committee, but informal discussions continued, in which both China and Taiwan's positions were taken into account, although they never met face to face. Visible progress was not made until 2008, after another change of government in Taiwan, back to the Kuomintang (KMT) under Ma Ying-jeou and its pro-détente policy in cross-Strait relations. In November 2008, Taiwan circulated its final offer to the GPA Committee, which was eventually adopted as GPA/96 in December 2008 (Committee on Government Procurement 2009a, Art. 11-12). A footnote was attached to Taiwan's Appendix I, with the following content (WTO 2009):

"In English only. With respect to the list of entities, refer to the relevant documents governing the modalities of accession to the Agreement on Government Procurement."

This footnote did not explicitly mention GPA/87, but for the informed reader, the connection is undeniable. Eventually, Taiwan had agreed to a footnote, which was drafted in the most diplomatic way possible. Taiwan's GPA accession finally entered into force on 15 July 2009 (Committee on Government Procurement 2009b).

The EU had had a very clear interest in Taiwan's GPA accession. First, Taiwan's government procurement regime was highly discriminatory towards foreign bidders, whilst at the same time, with Taiwan's economic development, many lucrative

\footnotetext{
${ }^{9}$ For instance, during this time, Taiwan attempted to use diplomatic titles for its WTO representation (see: Snyder 2003, 3).

${ }^{10}$ A similar solution had already been pondered but again abandoned in 2003 (Interview 42010 ).
} 
contracts were becoming available. ${ }^{11}$ Second, the EU was trying to increase the GPA's effectiveness by opening it up to more members; Taiwan was, therefore, a welcome addition (Committee on Government Procurement 2009a, Art. B para. 17). In the Council, the decision-making procedure on this issue was again qualified majority, so individual EU member states could not veto the decision. Research on the use of QMV suggests, however, that even in cases were QMV is possible, 75$80 \%$ of the decisions are not contested at Council level and, in practice, are therefore adopted by consensus (Hayes-Renshaw et al. 2006, 163). As there is no information available on how the vote was taken, it is statistically speaking more likely that it was not contested.

The GPA's membership criteria again justified EU support on the basis of Taiwan's functional sovereignty, but China's concerns received far more consideration here than in the WTO. The EU was actively involved in finding a compromise solution (for instance, it tabled the draft of Decision GPA/87 together with the US), but Taiwan's shift to an approach based on international legal sovereignty complicated the resolution of the issue. Eventually, the united efforts of the EU and the US were successful, but Taiwan's leadership change in 2008 and warmer cross-Strait relations appear to have been the main catalyst for this development.

The WTO and the GPA had membership criteria that made it easy to justify EU support for Taiwan's accession to both organisations. The focus of the last case study is a state-based organisation, where devising a policy of support was considerably more difficult for the EU.

\section{The World Health Organization}

The WHO deals with health issues on a global scale. It is a sub-organisation of the United Nations (UN), and its membership is, therefore, state-based (WHO 1946, Art. 3 ). The organisation also allows a number of non-state observers at the WHA, the general assembly of the WHO. In the organisation's legal documents, however, rules governing the admission of observers are scarce: the status allocated to them appears to be based mainly on practice (Burci and Vignes 2004, 36). Because of this ambiguous situation, many international actors, including the EU, were initially doubtful about whether Taiwan's functional sovereignty was sufficient for attaining observer status.

In 1997, Taiwan, for the first, time attempted to obtain observer status in the WHA under the name "Republic of China (Taiwan)". This application led to lengthy discussions between the diplomatic allies of Taiwan and China at the start of the 1997 WHA, discussions that proved impossible to resolve other than by a vote on whether Taiwan's request should be put on the WHA agenda. In the vote, 128 WHO members opposed inclusion, only 19 were for it and five countries abstained. The EU member states voted unanimously against the proposal, whilst the US abstained (WHA 1997, 5-24).

\footnotetext{
${ }_{11}$ According to European Commission estimates, over the 10 years leading up to 2008, all foreign suppliers had obtained a $20 \%$ share of Taiwan's total government procurement market, which amounted to a value of EUR 120 billion. Companies from the EU, however, had obtained only $3 \%$ of this sum in biddings in Taiwan (European Commission 2008).
} 
There was a clear difference between the positions of the US and the EU on this matter. In 1999, the US Congress began to adopt a series of bills. The earliest of these asked the US government actively to support "appropriate and meaningful participation" for Taiwan in the WHO (US Congress 1999, Sec. 1 (b)), but in 2001, this was changed to a call for support for observer status (US Congress 2001, Sec. 1 (b)). In 2001, President Bush stated (US Congress 2002, Sec. 1 (a) (12)) that whilst Taiwan's membership of the organisation was impossible, the US administration "has focused on finding concrete ways for Taiwan to benefit and contribute to the World Health Organization".

Ultimately, these annual Congress bills eventually were also the trigger for the first EU expression of interest in Taiwan's WHO participation. In 2001, a member of the European Parliament (MEP), having learned about the Congress bills, sent a written question to the Council asking about the EU's position on the same issue. The answer was cautious: the EU could not support the granting of any status to Taiwan in the WHO or any other UN organisation, but it welcomed more exchange of information between the WHO and Taiwan (European Parliament 2002, 14). From 2002 onwards, the European Parliament (EP) issued numerous resolutions calling for the EU to support Taiwan's WHO applications. The EP had little or no influence on EU decision-making concerning Taiwan's WHO participation, however, and the Commission's powers were also limited: the main actor in this area was the EU Council.

Over the coming years, Taiwan annually attempted to obtain WHA observer status on the basis of functional sovereignty, but its applications were rejected even before the voting stage. After several failed attempts, in 2002, it downgraded its application even further by beginning to apply as a "health entity" (Hickey 2007, 21), thereby removing any doubt about its trying to pose as a state with international legal sovereignty.

The tide finally began to turn in Taiwan's favour, albeit sadly, with the outbreak of the Severe Acute Respiratory Syndrome (SARS) in spring 2003. The SARS death toll in Taiwan was the third highest after China and Hong Kong. As soon as the outbreak started, Taiwan's health authorities requested help from the WHO, but it was 50 days before the first pair of experts was finally sent (Maloney et al. 2006, 109-114; Interview 10 2008). It was later learned that this mission took place only because China had authorised the WHO to have contact with Taiwan in this health emergency (Hickey 2006, 73; Permanent Mission of the People's Republic of China to the UN Office at Geneva and Other International Organisations in Switzerland 2004). Moreover, the role of the WHO experts sent to Taiwan was to observe rather than to give the Taiwanese health authorities active assistance in their fight against the epidemic (Interview 11 2008).

After the SARS crisis in Taiwan, the European Commission, too, made some statements on the merits of including Taiwan, specifically in the WHO and also generally, in the multilateral context, provided this was in line with the EU's "one China" policy and provided any implication of international legal sovereignty for Taiwan was avoided (European Voice 2003; Commission of the European Communities 2003, 10-11). China was quick to counter, however. In its EU Policy Paper (Ministry of Foreign Affairs of the People's Republic of China 2003, Part Three, Sec. I, Art. 2), China reminded the EU "[n]ot to support Taiwan's accession to or participation in any international organization whose membership requires statehood". 
In 2004, in the aftermath of the SARS crisis, Taiwan again applied for observer status in the capacity of a health entity. This led to a nearly 4-h discussion at the beginning of the WHA plenary session on whether to include the supplementary item on the WHA agenda. Again, the situation was resolved by a vote: 133 WHO members voted against including Taiwan's application on the WHA agenda and two countries abstained, but 25 votes supported the proposal (WHA 2004, 14-44).

The EU member states again voted unanimously against the proposal, but this time they decided to qualify their position in a statement. The representative of the Presidency of the Council of the European Union underlined that the EU had welcomed WHO assistance for Taiwan during the SARS outbreak and expressed hope that the WHO would find flexible ways to integrate Taiwanese experts better in its technical meetings and working groups (WHA 2004, 42). This stance later became known as "meaningful participation", which was only vaguely defined, and usually excluded the possibility of observer status. The US, together with Japan, went one step further and supported observer status for Taiwan in the WHO with a positive vote (WHA 2004, 32-33 and 41-42). Clearly, the US's assessment of whether observer status was compatible with Taiwan's functional sovereignty was different from that of the EU.

Another setback for Taiwan soon followed: in 2005, the WHO Secretariat concluded a secret Memorandum of Understanding (MOU) with China, ${ }^{12}$ laying down the ground rules for contact between the WHO and Taiwan (WHO 2005). The bottom line was that, except in cases of acute emergency, invitations for Taiwanese experts to WHO technical meetings and WHO technical assistance needed China's explicit approval after the WHO had already given its consent. Only in the event of emergency assistance to Taiwan did the WHO need merely to consult with China, without having to obtain its explicit consent.

This MOU framework undermined even Taiwan's functional sovereignty in health matters, as Beijing was given authority over all matters concerning Taiwan's participation in the WHO, as if it was, in practice, the central government superior to the province of Taiwan. Taiwan's government repeatedly expressed its objection to this arrangement. Furthermore, the long delays in dealing with Taiwan's requests both in Beijing and at WHO headquarters proved unworkable. Out of their 50 or so applications to participate in WHO technical meetings from 2005 to spring 2008, Taiwanese experts were able to attend only some 20 meetings (Interview 10 2008).

In 2007, Taiwan's government under Chen Shui-bian and the DPP decided to step up its approach, mainly for reasons to do with domestic political games, and to apply for full WHO membership as "Taiwan". The WHO Secretariat refused to accept the application letter (Interview 10 2008). Still, the move led to another round of discussions in the WHA when Taiwan's diplomatic allies enquired why its application was not on the agenda. Again a vote was held, this time on whether the agenda item headed "Admission of new Members and Associate Members" could be deleted without discussing Taiwan's application. Only 17 WHO members favoured the

\footnotetext{
12 According to newspaper reports, diplomatic cables published on WikiLeaks show evidence that the US was backing the MOU and that the Taiwanese government was informed about the ongoing negotiations (Shih 2011, 1).
} 
inclusion of the agenda item, 148 voted for its deletion and two members abstained. This time, the US as well as the EU voted to delete the agenda item (WHA 2007, 95-117). Full WHO membership was clearly perceived as a matter of international legal sovereignty. Nevertheless, Taiwan repeated its attempt in 2008, again to no avail.

After the 2008 WHA, Taiwan's approach returned to functional sovereignty. Shortly after the KMT was voted back into power, Ma Ying-jeou announced that his preferred WHO application would be for observer status under the name "Chinese Taipei", again deflecting any suspicions about Taiwan's aspirations to international legal sovereignty (Hsiao 2008). China reacted by announcing that Taiwan's WHO participation could be discussed as soon as cross-Strait talks were resumed (Xinhua.net 2008).

In April 2009, Taiwan and China held consultations on Taiwan's WHA observer status, resulting in an invitation for Chinese Taipei to observe the 2009 WHA (Shih et al. 2009, 1). Invitations also followed in 2010, 2011 and 2012 (WHO 2010, 57-58; WHO 2011, 60; The China Post 2012).

The political opposition in Taiwan objected, however, that the name "Chinese Taipei" did not portray Taiwan as a sovereign state and also that the consultations between Beijing and Taipei could be interpreted as Taiwan asking for China's permission (Chuang et al. 2009, 1). Furthermore, criticism has emerged that, despite the achievements of WHA observer status and Taiwan's inclusion in the WHO's International Health Regulations (IHR) in January 2009, Taiwan's experts were still excluded from most technical WHO meetings, whilst Taiwan was listed as "Taiwan, province of China" or "Taiwan, China" in official WHO documentation (Formosan Association for Public Affairs 2010, 14-15; Wang and Shih 2011).

Despite having previously rejected the possibility of Taiwan's becoming a WHA observer, in 2009, the EU Council welcomed the new development (Council of the European Union 2009). It appears that the distinction between functional sovereignty and international legal sovereignty in IOs has its grey areas and that in the WHO case, the EU was deeply concerned about China's interpretation. Once China changed its mind, the EU was also ready to accept that WHA observer status could be compatible with functional sovereignty.

To conclude this case study: European interests were rather diffuse in the case of Taiwan's WHO participation and were mainly discovered only after the SARS crisis. The EU's coordination framework within the WHO, relying on consensus between all EU member states, brought only weak support for Taiwan's improved technical participation in the WHO and a rejection of WHA observer status. Nevertheless, even when Taiwan applied for full membership, the EU did not abandon its support for greater participation, despite criticising Taiwan's new policy (WHA 2007, 108). The ambiguous criteria for observer status in the WHA certainly contributed to this low-profile stance by the EU, but what proved even more important was China's strong opposition. The EU settled for supporting meaningful WHO participation for Taiwan, a vague concept and one that left it largely to Taiwan and China to fill it with meaning. The US was less impressed by China's opposition, but US support for Taiwan's observer status was not sufficient to encourage the EU to follow the US' lead. 


\section{Six factors in a cross-case comparison}

In each of the case studies, six factors were singled out for their influence in shaping the EU's policy on Taiwan's participation in IOs. The value of each one having been briefly highlighted in the individual case studies, these factors will now be given further consideration in a cross-case comparison. This comparison will deliver some general conclusions as to what constellation of factors is necessary for the EU to become active in supporting Taiwan's participation in IOs, and it will include an examination of which factors were most and which least influential in shaping EU policy.

Factors internal to the EU

\section{EU interests}

The EU's interest in Taiwan's participation in IOs proved to be the single most important factor influencing European policies on Taiwan's entry into IOs. As the WHO case showed most clearly, the EU only increased its support when it could define its interest in the matter. In the case of the WHO, this was years after Taiwan had started its campaign. Initially, the relevant EU decision-making bodies had remained completely indifferent as long as they did not perceive a concrete danger to the EU or other countries, including Taiwan, posed by the gap left by Taiwan's absence from the WHO. It took SARS to trigger EU interest in this case. In the WTO and GPA cases, the definition of EU interests was easier, and it coincided with the beginning of the Taiwanese campaigns.

\section{EU decision-making}

The EU's decision-making process is perhaps the trickiest factor, and its influence is difficult to measure. The theory is relatively straightforward: in the economic realm, WTO and GPA, the EU decides by qualified majority, which is easier to achieve than the consensus necessary in foreign policy, as with the WHO. Indeed, the EU was more hesitant in supporting Taiwan's WHO participation than its membership of the two other organisations.

A closer look in the analysis of the case studies revealed, however, that the EU's final decision to agree to Taiwan's WTO accession was adopted by unanimity in order to honour the importance of the accession of both Taiwan and China. Taiwan's GPA accession also fell within the normal decision-making process of QMV, without there being evidence that this procedure was indeed applied. Other research highlights that, even when QMV is possible, member states prefer to establish a consensus rather than relying on a formal vote. This means that the decisions in the WTO and the WHO were undoubtedly taken unanimously or by consensus and that the same is very likely true for the GPA. It is, therefore, important to look not only at the final vote but at the whole process of establishing an EU position.

In Taiwan's accession to the WTO and the GPA, the EU was supportive from a very early stage, whereas in the $\mathrm{WHO}$, it was a long time in deciding whether it should take up the issue or not. Even when it decided that Taiwan's participation in 
the WHO would be in the EU's interest, in contrast to other actors, and especially the US, the EU only showed support for a less ambitious solution. Why did it make up its mind quickly in the WTO and GPA but not in the WHO? The obvious similarities in the cases of the GPA and the WTO were that both had to do with clear-cut economic interests. The EU's interest in Taiwan's WHO participation was not as obvious and, in addition, the problem concerned a highly sensitive issue, as the WHO was state-based.

It, therefore, appears that decision-making as such does not create an extra hurdle, as it proved easy to arrive at unanimity or consensus in the cases of the WTO and the GPA. It is, therefore, the nature of the problem that determines the outcome of the EU decision-making process, not the nature of this process as such.

Factors external to the EU

\section{Membership criteria in international organisations}

Once the European interest in Taiwan's participation in a particular IO was established, membership criteria determined the level of EU support for Taiwan's participation: what kind of solution could the EU envisage for Taiwan's entry into the relevant organisation?

In the WTO and the GPA, the membership criteria were conducive to Taiwan's participation. Both admitted separate customs territories as full members, for which Taiwan's functional sovereignty in foreign trade was sufficient. This was a relatively unambiguous basis from which the EU could push for Taiwan's accession. Problems or concerns that came up in the process were rooted not in the membership criteria but, mainly, in China's fears that Taiwan might eventually achieve international legal sovereignty through participation in those organisations, despite not having the status of a sovereign state within them.

In the WHO, the question of membership criteria was more problematic. Membership as such was reserved for states, so the EU discounted this option from the outset. WHA observer status was ambiguous for want of a clear definition in the organisation's rules. "Meaningful participation", although, or rather because, it did not confer any real status in the organisation and hence, did not imply international legal sovereignty, was eventually chosen as the most suitable option.

The EU still remained hesitant about investing this concept with specific meaning. This appears to have been a deliberate choice: as the WHO issue was so sensitive for the EU, it preferred China and Taiwan to define the rules of Taiwan's engagement in that organisation. China was endowed with more responsibility in decisions concerning Taiwan's WHO participation than in the other case studies examined in this research.

\section{Taiwan}

The influence of the Taiwanese campaign on EU policy was rather different from what had been assumed in the hypotheses guiding this research. The idea had initially been that the EU would support modest Taiwanese approaches to IOs on the basis of functional sovereignty, but shy away when Taiwan's strategy radically changed to the pursuit of international legal sovereignty. 
However, it emerged that the EU never supported Taiwan's approaches as such. It only supported a level of participation for Taiwan that would help it promote its own interests. Sometimes, for instance, in the WTO, Taiwan's approach overlapped with what the EU deemed to be in its interests, so it appeared as if the EU was supporting Taiwan's policy. Whenever Taiwan radicalised the goals it hoped to attain by participating in IOs, however, the EU still pursued its own interests and therefore, its own strategy.

The EU's interests did not go away merely because Taiwan radicalised its campaign to pursue international legal sovereignty. In such a situation, the EU even needed to increase its own activity, as then it not only had to support Taiwan's participation in the organisation in the teeth of opposition from China and other dissenting members, it also had to persuade Taiwan's government to agree to a solution that was less radical in terms of sovereignty. The EU again decreased its activity when Taiwan downgraded its international campaigns at a time of improved cross-Strait relations. This shows that Taiwan's campaign did have a decisive influence on the EU's strategy but in the opposite direction to what was initially assumed.

\section{China}

In this research, we have seen that, in the years under scrutiny, China gradually managed to increase its influence on the outcome of Taiwan's quests for participation in the IOs in question. As in all three cases, the EU was at the centre of the decisionmaking processes inside the organisations; it was, therefore, also thanks to the EU's policy that China was able to increase its impact on matters regarding Taiwan.

In the WTO, the earliest case study, the other members decided how to deal with China's opposition when, in 1992, they agreed to establish a GATT working party for the accession of Chinese Taipei. Some of China's concerns were reflected in this decision, for instance, in the stipulation that China had to accede to the organisation first, before Taiwan could join. However, they also tried to minimise China's impact by letting Taiwan's accession follow immediately after China's. At the same time, China's protest that Taiwan's GATT application was "utterly illegal" remained unanswered.

In the GPA, China's concerns, even coming from a mere observer, were taken very seriously, although none of the other GPA members had ever, in the earlier years of Taiwan's already ongoing negotiation process, seen the threat of sovereignty implications in Taiwan's Annex 1, listing its central government entities. However, not only were China's comments treated very carefully, in the GPA, China was even given a say in accepting the solution, as the chairman of the Committee on Government Procurement and representatives of other parties, above all the EU and the US, shuttled between China's and Taiwan's delegations in order to find a compromise acceptable to both sides. The search for a solution remained within the organisation, however: China and Taiwan did not negotiate with each other-they did not even establish bilateral contact.

In the WHO, the eventual solution stemmed from consultations between Taipei and Beijing; it did not emerge from within the framework of the organisation. China and Taiwan found a compromise, and China notified the WHO Secretariat that it would accept Taiwan's participation on stated terms. The other members might have 
put pressure on China to hold these negotiations and proposed ideas for a solution, but ultimately, this compromise was only possible because China was ready to talk to Taiwan's new government and vice versa after 2008. Furthermore, China managed to wield ultimate decision-making power even on the issue of Taiwan's WHO participation. For instance, Taiwan's WHA observer status needs to be annually renewed, so if China withdraws its support for this solution in the wake of a new government change in Taiwan, Taiwan's WHO participation could, at least theoretically, again be curtailed.

On the other hand, it also appears that China's stance has softened over the years. Whilst, in the early years of both campaigns, Taiwan's membership of the WTO was as unthinkable for China as its observer status in the WHA, right up to the very end, China still did its utmost to prevent Taiwan's accession to the WTO, or at least to dictate its terms unilaterally. The WHO case, however, shows that now China is even ready to talk with Taiwan about options to which it had voiced the strongest opposition only years earlier. This has certainly less to do with outward pressure than with the atmosphere across the Taiwan Strait, but it could be a window of opportunity for the EU and others to lobby for Taiwan's acceptance into other IOs where its participation would be of interest, such as the UN Framework Convention for Climate Change (UNFCCC) or the International Civil Aviation Organization (ICAO).

Finally, China's influence on the EU's policy towards IOs appears to be organisation-specific: in state-based organisations, such as the WHO, the EU's support was much more cautious than in the WTO or the GPA. Of course, this was partly because it was harder for the EU to define an interest in Taiwan's WHO participation, but the EU member states were also more careful about not provoking China on the issue of Taiwan's participation in an organisation open only to states and one in which China already was an important and influential member.

\section{United States}

In all the cases analysed here, the US had a similar interest to the EU in Taiwan's participation in the relevant IO. In all cases too, the US discovered its interest at roughly the same time as the EU, or even earlier. In the WHO case, US support was also stronger, as it decided to support WHA observer status for Taiwan, which the EU had deemed too controversial. Still, there was clearly ample room for cooperation: the EU and the US could jointly put pressure on China and other members of the relevant organisations to make room for Taiwan, and on Taiwan, if it radicalised its stance too much, to agree to a compromise solution. This cooperation was without doubt conducive to producing the positive results we see today, although the EU was mostly understood to be the junior partner in these operations.

All the same, the question remains: would the EU have supported Taiwan's participation in the IOs dealt with in this research if there had not been prior US support? After all, in the WHO case, it was only because of the previously established US policy that the agenda-setting process in the EU was eventually kicked off. Without the US, the EU would not have started considering its interests in the matter until a later stage. The sample here is too small, however, to answer this question with certainty. It could simply be coincidence that, in the cases of the WTO and the GPA, 
both the EU and the US started to show their support at the same time and that in no case study was the EU clearly ahead of the US.

To return to the issue of WHA observer status, the US' stronger support for this also shows that the EU did not merely emulate US strategy. It made its own decisions on the basis of an assessment of its own interests and potential problems that did not always lead to a policy identical to that of the US. The question is why the EU came to a different conclusion: was it resistance from amongst the member states or did the EU simply not agree that observer status would serve its interests best, preferring if Taiwan was better integrated into the organisation's information exchange networks and had access to emergency assistance? A mixture of both reasons is very likely.

\section{Conclusions}

The conceptualisation of sovereignty put forward in this study helps in drawing an accurate picture of the motives and interaction patterns of the actors involved. One practical reservation needs to be made about the concept of international legal sovereignty, however: although Taiwan's efforts to be treated like any other state in IOs, and China's fear of this situation were interpreted in this study in the light of international legal sovereignty, Taiwan would have never been able to fulfil the basic premise of international legal sovereignty solely through participation in IOs: diplomatic recognition by a large number of other states in the international community would also be needed.

Therefore, although the desire to be perceived as a normal state is actually an aspiration to international legal sovereignty, as only states with international legal sovereignty have unrestricted access to all areas of international relations, the best Taiwan could hope for, or the worst China realistically had to fear, was an extension of Taiwan's functional sovereignty to nearly all areas of international relations. This would mean that, on the basis of functional sovereignty, Taiwan could participate in virtually all IOs. Without diplomatic recognition, however, this would still fall short of international legal sovereignty.

Concerning the factors shaping EU policies in support of Taiwan's efforts to join IOs, some surprising conclusions had to be drawn in contrast to the initial hypotheses put forward in the introduction to this research. The most important factor in determining whether or not the EU would support Taiwan's participation in IOs was the EU's own interest, which was a precondition for any action it might take. On the question of how the EU supported Taiwan, or rather what form of participation the EU supported, the membership criteria of the IO in question and China's influence both on the EU and within the organisation in question proved, in particular, to be crucial. The US was also an important factor, as, at least in the WHO case, US action was instrumental in the agenda-setting process within the EU and also as the EU and the US had a broadly similar viewpoint, allowing them to take concerted action in support of Taiwan's participation in these IOs. The EU's decision-making processes and Taiwan's own strategy, however, ultimately had less influence on EU policy as long as the EU's interests were clear and shared by all EU member states. 


\section{References}

Burci GL, Vignes C (2004) World Health Organization. Kluwer, The Hague

Chang YK (1994) Special 301 and Taiwan: a case study of protecting United States intellectual property in foreign countries. Northwest J Int Law Bus 15(1):206-230

Cho H (2001) Taiwan's application to GATT/WTO: significance of multilateralism for an unrecognised state. Praeger, Westport

Cho H (2003) Stick to the name Taiwan knows. Taipei Times, 24 October, p 8. http://www.taipeitimes.com/ News/editorials/archives/2003/10/24/2003073152. Accessed 3 September 2010

Chuang J, Wang F, Huang S (2009) Protesters defend Taiwan sovereignty at WHA meet. Taipei Times, 20 May, p 1. http://www.taipeitimes.com/News/front/archives/2009/05/20/2003444076. Accessed 28 May 2009

Commission of the European Communities (2003) Commission policy paper for transmission to the council and the European Parliament: a maturing partnership - shared interests and challenges in EU-China relations, COM (2003) 533 final, 10 September

Committee on Government Procurement (2002) Minutes of the meeting held on 21 February 2002, GPA/ M/17, 2 May

Committee on Government Procurement (2006) Modalities of accession to the agreement on government procurement: decision of 2 June 2006, GPA/87

Committee on Government Procurement (2009a) Minutes of the formal meeting of 9 December 2008, GPA/M/35, 20 January

Committee on Government Procurement (2009b) Accession of the separate customs territory of Taiwan, Penghu, Kinmen and Matsu, GPA/100, 2 July

Communautés européennes, Le Conseil (1990) Résultats des Travaux du: Comité de l'article 113 (membres titulaires) en date du: 23 février 1990, 5014/90, 4180/90 GATT 7, 27 February (document on file with the author)

US Congress (1999) Act concerning the participation of Taiwan in the World Health Organization, H.R. 1794, Public Law 106-137, 106th Congress, 7 December. http://www.gpo.gov/fdsys/pkg/PLAW106publ137/html/PLAW-106publ137.htm. Accessed 28 January 2011

US Congress (2001) Act concerning the participation of Taiwan in the World Health Organization, H.R. 428, Public Law 107-10, 107th Congress, 28 May. http://www.gpo.gov/fdsys/pkg/BILLS107hr428enr/pdf/BILLS-107hr428enr.pdf. Accessed 20 January 2011

US Congress (2002) Act to amend Public Law 107-10 to authorize a United States plan to endorse and obtain observer status for Taiwan at the annual summit of the World Health Assembly in May 2002 in Geneva, Switzerland, and for other purposes, H.R. 2739, Public Law 107-158, 107th Congress, 4 April. http:// www.gpo.gov/fdsys/pkg/PLAW-107publ158/html/PLAW-107publ158.htm. Accessed 21 January 2011

GATT Council (1992) Minutes of meeting held in the Centre William Rappard on 29 September-1 October 1992, C/M/259, 27 October

Council of the European Union (2009) Declaration by the presidency on behalf of the EU on the occasion of the participation of Taiwan as an observer in the 62nd session of the World Health Assembly, P 50, 9486/09 (Presse 123), 8 May. http://europa.eu/rapid/pressReleasesAction.do?reference=PESC/09/ $50 \&$ format $=$ HTML\&aged $=0$ \&language $=$ EN\&guiLanguage $=$ en. Accessed 22 June 2009

European Parliament (1993) Report of the Committee on Foreign Affairs and Security on GATT membership for Taiwan, A3-0139/93, 29 April

European Union (1998) European Union and Taiwan conclude bilateral market access negotiations, IP/98/ 692, 23 July. http://europa.eu/rapid/pressReleasesAction.do?reference=IP/98/692\&format= HTML\&aged=1\&language $=$ EN\&guiLanguage $=$ en. Accessed 26 March 2009

European Union (2001) Commission approves the terms of accession of China and Taiwan, IP/01/1289, 19 September. http://europa.eu/rapid/pressReleasesAction.do?reference $=I P / 01 / 1289 \&$ format= HTML\&aged $=0 \&$ language $=E N \&$ guiLanguage $=$ en. Accessed 4 November 2010

European Parliament (2002) Written question P-1559/01 by Olivier Dupuis (TDI) to the Council. Observer status for Taiwan at the World Health Organisation. Official Journal of the European Union C093E, 18 April, p 14.

European Voice (2003) Interview with Chris Patten: 'One China' policy can still accommodate EU relations with Taiwan, 23 January. http://europa.eu.int/comm/external_relations/news/patten/ev230103.htm. Accessed 2 April 2005

European Commission (2008) European Commission welcomes the accession of Chinese Taipei to WTO Government Procurement Agreement, 9 December. http://rade.ec.europa.eu/doclib/docs/2008/december/ tradoc_141665.pdf. Accessed 24 May 2010 
Feinermann JV (1992) Taiwan and the GATT. Columbia Bus Law Rev 1:39-60

Formosan Association for Public Affairs (2010) World Health Assembly: more form than substance. Taiwan Communiqué 128:14-15

GATT (1947) The General Agreement on Tariffs and Trade

GATT (1990) Communication from the People's Republic of China, L/6635, 22 January

George AL, Bennett A (2004) Case studies and theory development. MIT, Cambridge

Hayes-Renshaw F, Van Aken W, Wallace H (2006) When and why the EU council of ministers votes explicitly. J Common Mark Stud 44(1):161-194

Hickey DV (2006) The high cost of excluding Taiwan from the WHO. In: Friedman E (ed) China's rise. Taiwan's dilemma and international peace. Routledge, Abingdon, pp 68-84

Hickey DV (2007) Foreign policy making in Taiwan: from principles to pragmatism. Routledge, Abingdon

Hsiao E (2008) New strategy could prove good WHO medicine. Taiwan J 20(15), 17 April. http:// taiwanjournal.nat.gov.tw/ct.asp?xItem=36457\&CtNode=122. Accessed 25 April 2008

Hsieh PL (2005) Facing China: Taiwan's status as a separate customs territory in the World Trade Organization. J World Trade 39(6):1195-1221

Interim Committee on Government Procurement (1994a) Communication from Chinese Taipei, GPA/IC/1, 4 August

Interim Committee on Government Procurement (1994b) Minutes of the meeting held on 29 June 1994, GPA/IC/M/1, 10 August

Interview 1 with a former EU official (2007) Brussels, Belgium, 22 February

Interview 2 with a former diplomat (2007) Geneva, Switzerland, 12 June

Interview 3 with a Taiwanese scholar (2008) Taipei, Taiwan, 6 October

Interview 4 with a diplomat involved in GPA negotiations (2010) Brussels, Belgium, 27 May

Interview 5 with a diplomat involved in GPA negotiations (2010) Brussels, Belgium, 26 April

Interview 6 with an EU official (2010) Brussels, Belgium, 31 May

Interview 7 with Taiwanese officials (2007) Geneva, Switzerland, 14 June

Interview 8 with a Taiwanese official (2008) Taipei, Taiwan, 7 October

Interview 9 with a European national official (2007) Stockholm, Sweden, 21 April

Interview 10 with a Taiwanese official (2008) Taipei, Taiwan, 18 April

Interview 11 with a Taiwanese official (2008) Taipei, Taiwan, 30 April

King G, Keohane RO, Verba S (1994) Designing social inquiry: scientific inference in qualitative research. Princeton University Press, Princeton

Kollek T (1988) Sharing united Jerusalem. Foreign Aff 67(2):156-168

Krasner SD (1999) Sovereignty: organized hypocrisy. Princeton University Press, Princeton

Lim P, Winkler S (2012) The European Union's relations with the Republic of China (Taiwan). In: Damm J, Lim P (eds) European perspectives on Taiwan. VS Verlag, Wiesbaden, pp 170-195

Maloney S, Olowokure B, Roth C (2006) Taiwan, China: from control to outbreak. In: WHO Western Pacific Region (ed) SARS: how a global epidemic was stopped. World Health Organization, Geneva, pp 109-114

Ministry of Foreign Affairs of the People's Republic of China (2003) China's EU Policy Paper, 13 October. http://www.fmprc.gov.cn/eng/topics/ceupp/t27708.htm. Accessed 10 November 2010

Nachmias N (1999) International economic assistance and sustainable development: a comparative analysis of the Palestinian and the Cambodian cases. Int J Public Sect Manag 12(3):273292

Permanent Mission of the People's Republic of China to the United Nations Office at Geneva and Other International Organizations in Switzerland (2004) Speech by H.E. Madame Wu Yi Head of Chinese Delegation, Vice Premier and Minister of Health on Taiwan-related Proposal at 56th World Health Assembly (05/19/03), 19 April. http://www.china-un.ch/eng/zmjg/jgthsm/t85541.htm. Accessed 28 December 2010

Pierce R (2008) Research methods in politics. Sage, Los Angeles

Shih H (2011) Cables show US' role in WHO-China MOU. Taipei Times, 12 September, p 1. http:// www.taipeitimes.com/News/front/archives/2011/09/12/2003513068. Accessed 12 September 2011

Shih H, Ko S, Hsu JW (2009) WHO invites 'Chinese Taipei' to WHA. Taipei Times, 30 April, p 1. http:// www.taipeitimes.com/News/front/archives/2009/04/30/2003442391. Accessed 30 April 2009

Snyder C (2003) Supporters in US more pessimistic. Taipei Times, 31 May, p 3. http://www.taipeitimes. com/News/taiwan/archives/2003/05/31/2003053380/print. Accessed 24 August 2010

The China Post (2012) First delegates for World Health Assembly meeting set off for Geneva, 19 May 2012. http:/www.chinapost.com.tw/taiwan/national/national-news/2012/05/19/341576/First-delegates.htm. Accessed 20 May 2012 
United States of America (2000) Congressional record: proceedings and debates of the 106th Congress, Second Session, July 27, 2000 to September 13, 2000 146(12). United States Government Printing Office, Washington, DC

Wang C, Shih HC (2011) WHO's terminology like a 'slap'. Taipei Times, 21 September, p 1. http:// www.taipeitimes.com/News/front/archives/2011/09/21/2003513787. Accessed 15 November 2011

WHA (1997) Fiftieth World Health Assembly, provisional verbatim record of the third plenary meeting, A50/VR/3, 5 May

WHA (2004) Fifty-seventh World Health Assembly, second plenary meeting, A57/VR/2, 17 May

WHA (2007) Sixtieth World Health Assembly, second plenary meeting, A60/VR/2, 14 May 2007

WHO (1946) Constitution of the World Health Organization

WHO (2005) Implementation of the Memorandum of Understanding between the WHO Secretariat and China, 12 July (document on file with the author)

WHO (2010) Sixty-third World Health Assembly: list of delegates and other participants, A63/DIV/1 Rev.1, 20 May

WHO (2011) Sixty-fourth World Health Assembly: list of delegates and other participants, A64/DIV/1 Rev.1, 24 May

Winkler S (2008) Can trade make a sovereign? Taiwan-China-EU relations in the WTO. Asia Europe J 6 (3-4):467-485

Winkler S (2009) EU responses to Taiwan's applications in the WTO, WHO and UN. In: Laursen F (ed) The EU as a foreign policy and security actor. Republic of Letters Publishing, Dordrecht, pp 235-257

WTO (1995) Agreement establishing the World Trade Organization

WTO (1996) Agreement on government procurement

WTO (2001a) WTO Ministerial Conference approves China's accession, Press/252, 10 November

WTO (2001b) WTO Ministerial Conference approves accession of Chinese Taipei, Press/253, 11 November

WTO (2008) Members and observers, 23 July. http://www.wto.org/english/thewto_e/whatis_e/tif_e/org6_ e.htm. Accessed 17 April 2011

WTO (2009) Agreement on government procurement done at Marrakesh on 15 April 1994: transmission of certified true copy of the terms of accession of the separate customs territory of Taiwan, Penghu, Kinmen and Matsu: notification of accession, WT/Let/647, 30 June

WTO (n.d.) The plurilateral agreement on government procurement (GPA). http://www.wto.org/english/ tratop_e/gproc_e/gp_gpa_e.htm. Accessed 19 March 2010

Xinhua.net (2008) Hu says opportunity for cross-Strait relations should be cherished, 28 May. http:// news.xinhuanet.com/english/2008-05/28/content_8272634.htm. Accessed 1 July 2008

Yeh AK (1990) Taiwan's membership in the General Agreement on Tariffs and Trade. In: Chu Y (ed) The role of Taiwan in international economic organizations, National Policy Research Series No. 1. Institute for National Policy Research Press, Taipei, pp 79-99 